\title{
PHYSICAL TRAINING TO PREVENT SPORTS INJURIES IN ATHLETES
}

\author{
TREINAMENTO FISICO PARA PREVENIR LESÕES ESPORTIVAS EM ATLETAS \\ ENTRENAMIENTO FÍSICO PARA PREVENIR LESIONES DEPORTIVASENATLETAS
}

Original Article

ARTIGO ORIGINAL

Artículo Original

\begin{abstract}
Guohai Zhou' (iD
(Physical Education Professional)

1. Jingling Institute of Technology, Nanjing, China.
\end{abstract}

\section{Correspondence:}

Guohai Zhou

Nanjing, China. 211169

cxli2020@126.com

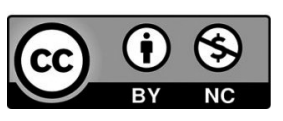

\begin{abstract}
Introduction: The purpose of physical training for athletes is to maintain and improve athletes' coordination, reaction ability, spatial orientation, anti-load ability, endurance, and other abilities. But the problem of injury in sports must be solved. Objective: To investigate the causes of athletes' injuries during physical training and proposes solutions for them. Methods: A questionnaire was applied to athletes to learn about their injuries in recent sports and their methods to avoid injuries. Results: Insufficient warm-up is the most common cause of injury. Other causes include site factors, fatigue, and excessive load. Sports injuries are the most common in extracurricular activities, while injuries are the least in sports training. The season in which the most damage occurs is winter, followed by autumn, and while spring shows the least injuries. Conclusion: The cause of sports injuries in physical training is related to insufficient warm-up activities. Physical training instructors should continuously improve their teaching level and provide athletes with the correct knowledge and skills to prevent sports injuries and protect themselves. As a result, the probability of sports injuries can be reduced as much as possible. Level of evidence Il; Therapeutic studies investigation of treatment results.
\end{abstract}

Keywords: Athletes; Physical Training, Human; Athletic injuries; Sports.

\section{RESUMO}

Introdução: O objetivo do treinamento físico para atletas é manter e aperfeiçoar suas habilidades, tais como coordenação, tempo de reação, orientação espacial, resistência de carga, resistência física, entre outras. Mas o problema das lesões esportivas precisa ser resolvido. Objetivo: Investigar as causas dos ferimentos de atletas durante treinamentos físicos e propor soluções para elas. Método: Um questionário foi aplicado aos atletas para investigar suas lesões esportivas recentes e seus métodos para evitar lesões. Resultados: A falta de aquecimento é a causa mais comum de lesões. Outras causas incluem fatores relacionados ao local, fadiga e carga excessiva. Ferimentos esportivos são os mais comuns entre atividades extracurriculares, enquanto no treinamento esportivo lesões são as ocorrências menos comuns. A estação na qual a maior quantidade de lesões ocorre éo inverno, seguida do outono, enquanto a primavera apresenta o menor número de lesões. Conclusão: A causa de ferimentos esportivos em treinamentos físicos relaciona-se a atividades de aquecimento insuficientes. Instrutores de treino deveriam continuamente aprimorar seu nivel de ensino e fornecer aos atletas o conhecimento e as habilidades necessárias para que possam se prevenir contra ferimentos esportivos e se proteger; assim, a probabilidade de lesões esportivas pode ser reduzida ao mínimo possível. Nível de evidência Il; Estudos terapêuticos - investigação de resultados de tratamento.

Descritores: Atletas; Condicionamento Físico Humano; Traumatismos em Atletas; Esportes.

\section{RESUMEN}

Introducción: El objetivo del entrenamiento físico para atletas es mantener y perfeccionar sus habilidades, tales como coordinación, tiempo de reacción, orientación espacial, resistencia de carga, resistencia física, entre otras. Pero el problema de las lesiones deportivas necesita ser resuelto. Objetivo: Investigar las causas de las lesiones de atletas durante entrenamientos físicos y proponer soluciones para ellas. Método: Un cuestionario fue aplicado a los atletas para investigar sus lesiones deportivas recientes y sus métodos para evitar lesiones. Resultados: La falta de calentamiento es la causa más común de las lesiones. Otras causas incluyen factores relacionados al lugar, fatiga y carga excesiva. Lesiones deportivas son más comunes entre actividades extracurriculares, mientras que en el entrenamiento deportivo lesiones son las menos frecuentes. La estación en la cual la mayor cantidad de lesiones ocurre es el invierno, seguida del otoño, mientras que la primavera presenta el menor número de lesiones. Conclusión: La causa de heridas deportivas en entrenamientos físicos se relaciona a actividades de calentamiento insuficientes. Instructores de entrenamiento deberían continuamente mejorar su nivel de enseñanza y proveer a los atletas el conocimiento y las habilidades necesarias para que puedan prevenirse contra lesiones deportivas y protegerse; asi, la probabilidad de que se produzcan lesiones deportivas puede reducirse al mínimo. Nivel de evidencia ll; Estudios terapéuticos investigación de resultados de tratamiento.

Descriptores: Atletas; Acondicionamiento Físico Humano; Traumatismos en Atletas; Deportes. 


\section{INTRODUCTION}

The physical training of athletes is to maintain and improve athletes' coordination, reaction ability, spatial orientation, anti-load ability, endurance, and other abilities. However, various sports injuries often occur in the process of physical training. ${ }^{1}$ This has become the main reason hindering the development of physical fitness training for athletes. Carry out effective prevention and treatment work for sports injuries in athletes' physical training to find the causes of sports injuries in athletes' physical training. ${ }^{2}$ This study surveyed related content of athletes to understand the incidence, occasions, and causes of sports injuries in athletes' physical fitness training. The results are reported below.

\section{METHOD}

\section{Survey object}

We use a completely random sampling method to select 300 athletes as the survey subjects. ${ }^{3}$ The athletes have suffered sport recently s injuries in physical training recently (with

\section{Research methods}

A questionnaire was drawn up by consulting relevant literature to conduct a face-to-face questionnaire survey on the survey's subjects. The content of the questionnaire includes general information about the research object. ${ }^{4}$ The article understands the differences in general conditions and self-protection consciousness between athletes who have recently suffered sports injuries and those who have not suffered injuries. It analyzes the causes of injuries for athletes who have sports injuries.

\section{Motion model design}

Leg stiffness is calculated by dividing the peak vertical ground reaction force by the leg displacement. The change in leg length refers to the distance between the greater trochanter of the hip and the ground position during exercise. Most studies mix different methods such as ground reaction force or leg length displacement changes to calculate stiffness, resulting in some studies even having the same or similar calculation methods (Equation 1). However, there are also differences in interpretation due to extremely obvious differences in definitions. $\Delta L$ represents the change in the length of the leg from the foot touching the ground to the mid-support period. ${ }^{5}$ The initial length of the leg is defined as the distance from the greater trochanter of the femur to the ground when standing. $\Delta y_{c}$ represents the vertical displacement of the runner's center of gravity during the touchdown period. $t_{c}$ represents the time to ground. $V$ represents the average running speed. Some scholars have assumed a sinusoidal GRF to calculate leg length changes in the leg stiffness model. ${ }^{6}$ Calculate the degree of leg compression (Equation 2). Where $\Delta L$ is the abrupt change of the leg displacement, and $L_{O}$ is the leg length. $M$ is the body mass. $t_{c}$ is the ground contact time, $g$ is the acceleration due to gravity, and $T D$ is the moment of ground contact. Here $\Delta L$ is calculated based on $\Delta y_{c}$ and half of the phase angle $\theta$ of the leg spring when it touches the ground. $L_{O}$ is defined as the distance from the greater trochanter to the ground when upright. $\Delta y_{c}$ is obtained by quadratic integration of the vertical ground force against time.

$$
K_{\text {leg }}=\frac{F_{\max }}{\Delta L}
$$

$$
\Delta L=L_{O}-\sqrt{L_{O}^{2}-\left(v \times \frac{t_{c}}{2}\right)^{2}}+\Delta y_{c}
$$

$$
\Delta L=L_{O}+\frac{F_{\max } \times t_{c}^{2}}{m \times \pi^{2}}-\frac{g \times t_{c}^{2}}{g}-\left(L_{O} \times \sin \alpha_{T D}\right)
$$

$\Delta L=\Delta y_{c}+L_{O} \times(1-\cos \theta)$

\section{Statistical analysis}

We use SPSS16.0 to perform statistical analysis on the data. The enumeration data used the $\times 2$ test.

\section{RESULTS}

\section{Basic information of survey subjects}

The gender of the 300 survey subjects selected this time is all male. One hundred seventeen athletes suffered sports injuries, and the incidence of sports injuries was 39.0\%. The difference in age composition between the injured group and the entire group was statistically significant $(x 2=20.342, P<0.001)$, and the difference in the distribution of exercise types was not statistically significant ( $X 2=0.057, P>0.05)$. See Table 1 for the distribution of specific genders and sports types.

\section{Causes of sports injuries}

In 117 patients with sports injuries, the investigation of the causes of sports injuries has been added. The results showed that technical errors (36.8\%), insufficient preparation activities (33.3\%), and inattention (28.2\%) were the main causes of sports injuries. (Table 2)

In the survey results of athletes'self-protection measures during physical fitness training, the three items of "pre-exercise preparation activities," "actions taken when fatigue occurs during exercise," and "behaviors taken when uncomfortable during exercise" occurred in the injured group and the entire group. ${ }^{8}$ The difference is statistically significant. There was no difference in "knowledge of the relationship between technical actions and sports injuries" and "knowing the emergency treatment methods of sports injuries". (Table 3)

Table 1. Basic information of survey respondents.

\begin{tabular}{c|c|c|c|c|c}
\hline \multirow{2}{*}{ Project } & \multirow{2}{*}{ Total } & \multicolumn{2}{|c|}{ Injury group } & \multicolumn{2}{c}{ Uninjured group } \\
\cline { 4 - 7 } & & $\mathbf{N}$ & Composition ratio & N & Composition ratio \\
\hline Age & & & & & \\
\hline $20 \sim$ & 88 & 46 & 52.3 & 42 & 47.7 \\
\hline $25 \sim$ & 105 & 47 & 44.8 & 58 & 55.2 \\
\hline $30 \sim$ & 68 & 15 & 22.1 & 53 & 77.9 \\
\hline $35 \sim$ & 39 & 9 & 23.1 & 30 & 76.9 \\
\hline Exercise type & & & & & \\
\hline Low-intensity exercise & 141 & 56 & 39.7 & 85 & 60.3 \\
\hline High-intensity exercise & 159 & 61 & 38.4 & 98 & 61.6 \\
\hline Total & 300 & 117 & 39 & 183 & 61 \\
\hline
\end{tabular}

Table 2. Causes of sports injuries in 117 athletes.

\begin{tabular}{c|c|c}
\hline Causes of sports injuries & N & Incidence \\
\hline Inadequate preparation & 39 & 33.3 \\
\hline Technical error & 43 & 36.8 \\
\hline Sports equipment problem & 16 & 13.7 \\
\hline Sports ground problem & 12 & 10.3 \\
\hline Inattention & 33 & 28.2 \\
\hline Poor physical condition & 28 & 23.9 \\
\hline Improper protection measures & 8 & 6.8 \\
\hline Other & 11 & 9.4 \\
\hline
\end{tabular}


Table 3. Athletes take self-protection measures during physical training.

\begin{tabular}{|c|c|c|c|c|c|c|}
\hline \multirow[t]{2}{*}{ Project } & \multicolumn{2}{|c|}{ Injury group } & \multicolumn{2}{|c|}{$\begin{array}{l}\text { Uninjured } \\
\text { group }\end{array}$} & \multirow[t]{2}{*}{$x^{2}$} & \multirow[t]{2}{*}{$P$} \\
\hline & $\mathrm{n}$ & $\%$ & $\mathrm{n}$ & $\%$ & & \\
\hline $\begin{array}{l}\text { Normal pre-exercise } \\
\text { preparation activities }\end{array}$ & & & & & 8.27 & $<0.05$ \\
\hline No warm-up & 29 & 24.8 & 22 & 12 & & \\
\hline Simple warm-up & 37 & 31.6 & 66 & 36.1 & & \\
\hline Adequate preparation & 51 & 43.6 & 95 & 51.9 & & \\
\hline $\begin{array}{l}\text { Understanding of the relationship } \\
\text { between technical movements } \\
\text { and sports injuries }\end{array}$ & & & & & 0.02 & 0.89 \\
\hline There are relationships & 89 & 76.07 & 138 & 45.41 & & \\
\hline No relation & 28 & 23.93 & 45 & 24.59 & & \\
\hline $\begin{array}{l}\text { Action to take when fatigue } \\
\text { occurs during exercise }\end{array}$ & & & & & 5.97 & $<0.05$ \\
\hline Keep moving & 75 & 64.1 & 91 & 49.73 & & \\
\hline Stop, rest & 42 & 35.9 & 92 & 50.27 & & \\
\hline $\begin{array}{c}\text { Uncomfortable behavior } \\
\text { during exercise }\end{array}$ & & & & & 10.27 & $<0.01$ \\
\hline Keep moving & 44 & 37.61 & 42 & 22.95 & & \\
\hline Stop, rest & 39 & 33.33 & 58 & 31.69 & & \\
\hline $\begin{array}{l}\text { Stop, seek medical } \\
\text { attention promptly }\end{array}$ & 34 & 29.06 & 83 & 45.36 & & \\
\hline $\begin{array}{l}\text { Know the emergency } \\
\text { treatment of sports injuries }\end{array}$ & & & & & 0.29 & 0.59 \\
\hline Don't know & 32 & 37.35 & 45 & 24.59 & & \\
\hline Know & 85 & 72.65 & 138 & 75.41 & & \\
\hline
\end{tabular}

\section{DISCUSSION}

The results of this study show that athletes'sports injuries have nothing to do with the types of athletes and are related to the age of the athletes. Younger athletes have a higher probability of sports injuries. ${ }^{9}$ In previous similar studies, some scholars also believed that athletes'sports injuries were related to age. Younger athletes are susceptible to acute injuries, such as sports injuries, while older athletes who fly for a long time are susceptible to chronic injuries. In the analysis of the causes of sports injuries, it can be seen that technical errors (36.8\%), insufficient preparation activities (33.3\%), and inattention (28.2\%) are the main reasons for sports injuries. Therefore, this suggests that we should take targeted prevention for the main causes of sports injuries. A comparison of self-protection measures between athletes who have recently suffered injuries and athletes who have not suffered injuries. The two groups are "pre-exercise preparation activities," "actions taken when fatigue occurs during exercise," and "behaviors taken when uncomfortable during exercise."The difference between them is statistically significant. ${ }^{10}$ This further verifies that the causes of sports injuries in physical training are related to insufficient warm-up activities. At the same time, this is also related to failure to take appropriate actions when fatigue and discomfort occur during exercise. Regardless of the injury group and the entire group, the accuracy of "knowledge of the relationship between technical actions and sports injuries" and "knowing the emergency treatment of sports injuries" was higher, and there was no difference between the two groups.

During the exercise, athletes must observe discipline and pay attention to safety. Serious and serious training, especially in difficult technical training, adequate preparation activities are an important part of reducing injury.

Exercising too much makes it easy to overburden or fatigue the body and leads to a decline in exercise capacity. ${ }^{11}$ To avoid injuries of this type, coaches must know about sports medicine and abide by the basic training principles. The coach arranges the amount of exercise scientifically according to the time, intensity, and density, strengthening the athlete's self-supervision. ${ }^{12}$ The movements should be from simple to complex, from easy to difficult, from decomposition to overall movement. In the game, follow the laws and rules.

Strengthen medical supervision and pay attention to the safety of the equipment. Sports training must be highly scientific, and safety inspections of sports venue equipment and personal protective equipment must be strengthened. People who are not fit should not participate in the competition. ${ }^{13}$ Athletes should do a good job of self-supervision during sports activities and pay attention to whether they have symptoms of fatigue at all times. Pay special attention to the local reactions of the body organs. When there is an adverse reaction, it is impossible to increase the amount of exercise, and it is not advisable to practice more difficult movements.

\section{CONCLUSION}

It is recommended that preventive measures be taken from the following aspects regarding sports injuries in athletes' physical training. Screening and discovering the predisposing factors of sports injuries is the first step to protect and prevent injuries. After finding out the predisposing factors of the susceptible population, effective interference measures are formulated to reduce the occurrence of sports injuries. Since the interaction of multiple factors causes sports injuries, further studies on multiple factors are needed in the future to obtain sufficient evidence. Secondly, athletes should improve their awareness of sports injury prevention. Pay attention to taking self-protection measures in the process of physical training. Physical training instructors should continuously improve their teaching level. They need to provide athletes with the correct knowledge and skills to prevent sports injuries and self-protection. In this way, the probability of sports injuries can be reduced to the greatest extent.

The author declare no potential conflict of interest related to this article

\section{REFERENCES}

1. Dohman Z, Bavli O. Effectivenes of Hipermobility on Sport Injury among Young Players. Journal of Sports Research. 2020;7(1):44-9.

2. Orchard JW, Meeuwisse W, Derman W, Hägglund M, Soligard T, Schwellnus M et al. Sport medicine diagnostic coding system (SMDCS) and the orchard sports injury and illness classification system (OSIICS): revised 2020 consensus versions. British journal of sports medicine. 2020;54(7):397-401.

3. Hulme A, Thompson J, Nielsen RO, Read GJ, Salmon PM. Towards a complex systems approach in sports injury research: simulating running-related injury development with agent-based modelling. British journal of sports medicine. 2019;53(9):560-9.

4. Kim HC, Park KJ. Type of injury and recovery time in elite adolescent Korean judo athletes: An epidemiological study. International Journal of Sports Science \& Coaching. 2021;16(3):682-9.

5. Lindanger L, StrandT, Mølster AO, Solheim E, Inderhaug E. Return to play and long-term participation in pivoting sports after anterior cruciate ligament reconstruction. The American journal of sports medicine. 2019;47(14):3339-46

6. Udby CL, Impellizzeri FM, Lind M, Nielsen RØ. How has workload been defined and how many workload-related exposures to injury are included in published sports injury articles? A scoping review. Journal of orthopaedic \& sports physical therapy. 2020;50(10):538-48.

7. Nielsen RO, Bertelsen ML, Møller M, Hulme A, Mansournia MA, Casals Met al. Methods matter: exploring the'too much, too soon'theory, part 1: causal questions in sports injury research. British journal of sports medicine. 2020;54(18):1119-22.
8. Lystad RP, Curtis K, Browne GJ, Mitchell RJ Incidence, costs, and temporal trends of sports injury-related hospitalisations in Australian children over a 10-year period: a nationwide population-based cohort study. Journal of science and medicine in sport. 2019;22(2):175-80.

9. Grygorowicz M, Michałowska M, Jurga P, Piontek T, Jakubowska H, Kotwicki T. Thirty percent of female footballers terminate their careers due to injury: a retrospective study among polish former players. Journal of sport rehabilitation. 2019;28(2):109-14.

10. Martínez-Silván D, Wik EH, Alonso JM, Jeanguyot E, Salcinovic B, Johnson A et al. Injury characteristics in male youth athletics: a five-season prospective study in a full-time sports academy. British journal of sports medicine. 2021;55(17):954-60.

11. Lystad RP, Alevras A, Rudy I, Soligard T, Engebretsen L. Injury incidence, severity and profile in Olympic combat sports: a comparative analysis of 7712 athlete exposures from three consecutive Olympic Games. British journal of sports medicine. 2021;55(19):1077-83.

12. Medina McKeon JM, McKeon PO, Nedimyer AK. Sports Injury Epidemiology: Foundation of Evidence of, by, and for Athletic Trainers. Journal of Athletic Training. 2021;56(7):606-15.

13. Ackerman IN, Bohensky MA, Kemp JL, de Steiger R. Likelihood of knee replacement surgery up to 15 years after sports injury: A population-level data linkage study. Journal of science and medicine in sport. 2019;22(6):629-34. 